\title{
QUANTITATIVE POLLEN ANALYSIS OF BEE HONEY AT CERTAIN APIARIES IN QALYUBIA GOVERNORATE AND AVAILABLE HONEY IN LOCAL MARKET, EGYPT
}

\author{
Mai, M. Hassanien; M.E. M. El- Sherif; A.A.A. Salem and M.A.M. Ali \\ Plant Protection Dept., Fac., of Agric., Ain Shams Univ., Cairo, Egypt
}

Keywords: Bee honey; Pollen analysis; Quantitative pollen analysis

\section{ABSTRACT}

A new proposal method for quantitative pollen analysis of pollen grains in each gram of bee honey was described, using a Neubauer improved chamber for leucocytes and erythrocytes counting. The study was conducted at the Bee Research Unit, Dept. of plant protection, Faculty of Agriculture, Ain Shams University, Shoubra El-kheimah, Al Qalyubia, Egypt on 36 samples of citrus and clover honeys. 18 samples were collected from 5 apiaries under study in Qalyubia Governorate; Kanater, Shalakan, Tookh, Khankah and Shoubra El kheimah and 18 samples were collected from local market in 5 Governorates in Egypt; Cairo, Giza, Qalyubia, Gharbia and Sharqia, during their seasons of production in 2013, 2014 and 2015. The results showed that $2.8 \%$ of the samples were poor in their content of pollen grains (200010000 pollen grains /g honey), $77.8 \%$ of the samples were rich in their content of pollen grains (10000-50000 pollen grains /g honey), $11.1 \%$ of the samples were more rich in their content of pollen grain (50000 -100000 pollen grains /g honey) and $8.3 \%$ of the samples were very rich in their content of pollen grain ( $>100000$ pollen grains $/ g$ honey).

\section{INTRODUCTION}

Bee honey contains numerous pollen grains (mainly from plants bees feed on) of which provide exact information for the quality of honey. Quantitative pollen analysis is a branch of palynology (science of pollen and spores) and used in the microscopic investigation of bee honey. The microscopic analysis is a widely accepted assumption by many scientists (Oddo and Piro, 2004). The method provides essential information about the hygienic aspects of bee honey production, its contamination with mineral dust (Louveaux et al 1978). The approved quantitative pollen analysis method was developed and proposed by the International Commission for Bee Botany in 1978 (Louveaux et al 1978). The method was validated in 2004 (von der Ohe et al 2004), and afterwards, widely used in European laboratories for bee honey analysis. It is among the methods used for description of European honey types in the beginning of the $21^{\text {st }}$ century (Persano Oddo and Piro, 2004).

Haemocytometer (Neubauer improved chamber) which used in routine laboratory practice for leucocytes and erythrocytes counting (Heldrup et al 1992), also used for counting pollen grains from plants (Delaplane et al., 2013), and to evaluate the number of pollen grains attached to bees (Human et al 2013). Therefore, in the present work it was used as a new method for quantitative pollen analysis of pollen grains in each gram honey.

In Egypt, most of researches were conducted on chemical and physical properties [El- Sherbiny et al (1980), Hassan (1985); Nour (1988); Gomaa (2004); Rateb (2005); Faraj (2007) and Ismail (2013)]. The accurate determination of bee honey type especially pollen analysis requires more detailed research. The proposed new method aims to determine the number of pollen grains in each gram of honey in all collected samples to evaluate their quality. 


\section{MATERIALS AND METHODS}

36 samples of citrus and clover honeys were collected from the 5 apiaries under study in Qalyubia Governorate and local market from 5 Governorates of Egypt, during their seasons of production in 2013, 2014 and 2015 as follows:

1- 9 citrus honey samples from certain apiaries in

Qalyubia Governorate situated in Kanater, Shalakan, Tookh, Khankah and Shoubra El kheimah included: $\mathrm{H} 1, \mathrm{H} 2$ and $\mathrm{H} 3$ in 2013, $\mathrm{H} 13, \mathrm{H} 14$ and $\mathrm{H} 27$ in 2014 and H20, H21 and $\mathrm{H} 25$ in 2015.

2- 9 clover honey samples from the same apiaries included: $\mathrm{H} 7, \mathrm{H} 8$ and $\mathrm{H} 9$ in 2013, H17, H29 and $\mathrm{H} 32$ in 2014 and $\mathrm{H} 30, \mathrm{H} 31$ and $\mathrm{H} 33$ in 2015.

3- 9 citrus honey samples from the local markets situated in Cairo, Giza, Qalyubia, Gharbia and Sharqia Governorates included: $\mathrm{H} 4, \mathrm{H} 5$ and $\mathrm{H} 6$ in 2013, H15, H18 and $\mathrm{H} 22$ in 2014 and $\mathrm{H} 19$, $\mathrm{H} 24$ and H26 in 2015.

4- 9 clover honey samples from the local markets situated in the same Governorates included: $\mathrm{H} 10, \mathrm{H} 11$ and $\mathrm{H} 12$ in 2013, H16, H36 and H37 in 2014 and H28, H34 and H35 in 2015.

For quantitative analysis of pollen grains in each gram of bee honey, $10 \mathrm{~g}$ of each honey sample were weighed in a graduated cylinder. Distilled water was added to a total volume of $20 \mathrm{~cm}^{3}$. The obtained honey solution was divided into two aliquots of $10 \mathrm{~cm}^{3}$ in graduated centrifuge tubes. The tubes were centrifuged at $2500 \times \mathrm{g}$ for $10 \mathrm{~min}$. With an automated pipette, $9 \mathrm{~cm}^{3}$ of the supernatant were discarded from each tube. To the remaining amount of $1 \mathrm{~cm}^{3}$ in each of the two tubes, $5 \mathrm{~cm}^{3}$ distilled water were added to a total volume of 6 $\mathrm{cm}^{3}$. The two tubes were centrifuged at $2500 \times \mathrm{g}$ for $10 \mathrm{~min}$. With an automated pipette, $5 \mathrm{~cm}^{3}$ of the supernatant were discarded from each tube. From the remaining $1 \mathrm{~cm}^{3}$ honey solution, after a thorough mixing with a glass rod, $0.1 \mathrm{~mm}^{3}(\mu \mathrm{l})$ samples were taken with automated pipettes from the bottom of each tube. The amount was chosen due to the experimentally established fact that a volume of .01 $\mu$ f fills entirely, without leaking, the two semireflective segments of the Neubauer improved chamber after placing the cover glass.

Under direct light, the positions of the gridded areas were identified and the $0.1 \mu \mathrm{l}$ samples were pipetted in the middle of grids, resulting in two drops on each grid. A thin coverslip (Cover glass, $24 \times 32 \mathrm{~mm}$, thickness 0.13-0.17 mm), was then carefully placed perpendicularly to the wide side of the chamber to cover entirely the gridded areas and to contact tightly the chamber edges Fig. (1).

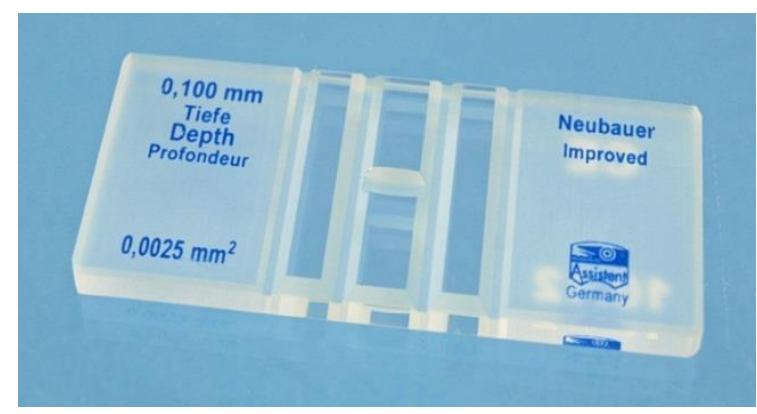

Fig.1. Neubauer improved chamber

Using a light microscope, eyepiece lens 10x and objective lens $10 x / 0.24$, the two grids of the chamber were brought into focus and all pollen grains within them were counted using objective lens $40 x / 0.26$, including those grains within each medium square and those that are over the top and right sides of the square (even when they are partially out) Fig. (2).

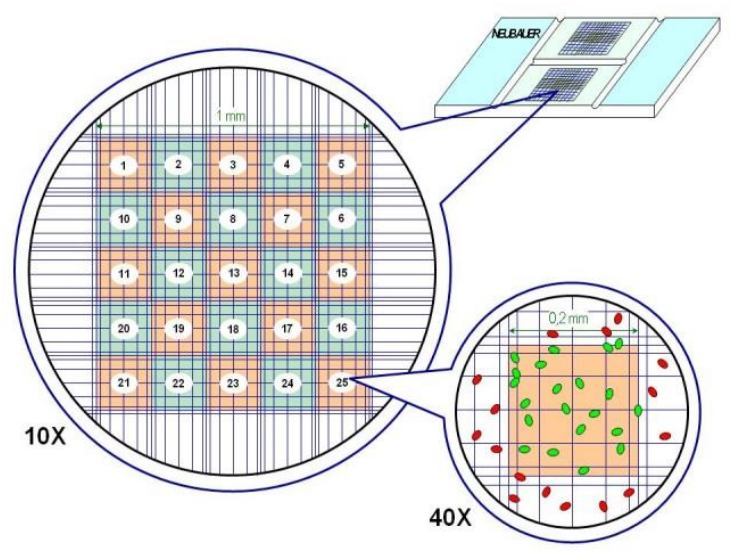

Fig. 2. Grid for pollen counting in Neubauer's improved cell counting chamber

Pollen grains in both segments of the chamber were counted and the arithmetic mean (A) was calculated. The number of pollen grains in $\mathbf{1 0} \mathbf{g}$ honey is calculated by the equation:

$$
X=A \times 50000
$$

where:

$\mathrm{X}$ - number of pollen grains in $10 \mathrm{~g}$ honey;

$A$ - arithmetic mean of pollen grains counted in the two grids of the chamber $(=(\mathrm{N} 1+\mathrm{N} 2) / 2)$. 

governorate and available honey in local market, Egypt

50000- coefficient for calculation of sample volume

\section{For obtaining the coefficient $\mathbf{5 0 0 0 0}$}

Neubauer 's improved chamber has 9 large squares each with a $1 \mathrm{~mm}^{2}$ area, and each of them could hold $0.1 \mathrm{~mm}^{3}$ of honey solution because when putting the sample under the coverslip, the cell suspension reaches a height of $0.1 \mathrm{~mm}$ (Neubauer's improved cell counting chamber, 2003). Taking these data into account, and considering one of the large squares, the volume will be:

$$
1 \times 1 \times 0,1=0,1 \mathrm{~mm}^{3}=10^{-4} \mathrm{ml}
$$

1. According to Hornitzky, 2009 the counted N pollen grains in 5 of the medium squares (that is, in 25 medium squares Fig. (3), the concentration of our sample will be:

\section{$N \times 10^{4}$ pollen grain $/ \mathrm{ml}$}

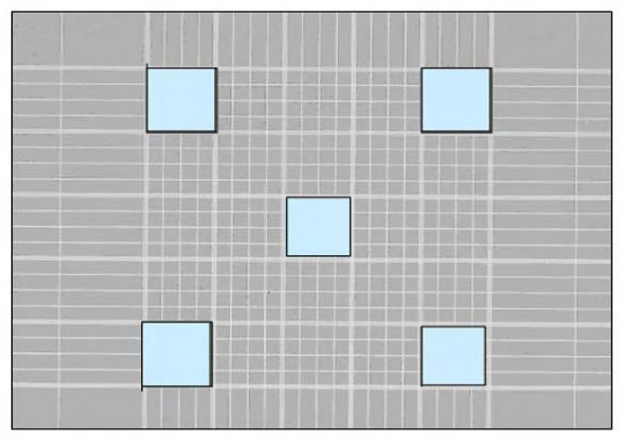

Fig. 3. Five medium squares (Hornitzky, 2009)

2. All the pollen grains within each medium square (total 25 square) and those that are over the top and right sides of the square (even when they are partially out) are counted so the final equation is: $N{ }^{*} 5^{*} 10^{4}=N * 50000$

So, the number of pollen grains in each gram honey is calculated by the equation:

$$
X=A \times 50000 / 10
$$

where:

$X$ - number of pollen grains in each gram honey $A-$ arithmetic mean of pollen grains counted in the two grids of the chamber $(=(\mathrm{N} 1+\mathrm{N} 2) / 2)$.

5000 - coefficient for calculation of sample volume

\section{Example:}

For obtaining the arithmetic mean $\left(x^{-}\right)$of pollen grains counted in the two grids of the chamber for 10 tests $\left(A_{1-10}\right)$ were as followed:

10 readings done in longer time intervals (1 month) were made from each honey sample, the results for pollen grains number in both chamber grids for the ten tests $\left(A_{1-10}\right)$ were as followed:

$A_{1}=16 / 2$ (number of chamber grids) $=8$

$A_{2}=15 / 2=7.5$

$A_{3}=15 / 2=7.5$

$A_{4}=16 / 2=8$

$A_{5}=15 / 2=7.5$

$A_{6}=15 / 2=7.5$

$A_{7}=16 / 2=8$

$A_{8}=15 / 2=7.5$

$A_{9}=16 / 2=8$

$A_{10}=16 / 2=8$

$\mathbf{X}^{-}=7.75$

s. e. (standard error) $=0.08$

The calculated pollen grain numbers in $1 \mathrm{~g}$ honey for each test run according to the formula $\left(X_{1-10}\right)$ was as followed:

$X_{1}=8 \times 5000=4 * 10^{4}$ pollen grains $/ 1 \mathrm{~g}$ honey

$\mathrm{X}_{2}=7,5 \times 5000=37.5^{*} 10^{3}$ pollen grains $/ 1 \mathrm{~g}$

$X_{3}=7,5 \times 5000=37.5^{*} 10^{3}$ pollen grains $/ 1 \mathrm{~g}$

$X_{4}=8 \times 5000=4 * 10^{4}$ pollen grains $/ 1 \mathrm{~g}$

$X_{5}=7,5 \times 5000=37.5^{*} 10^{3}$ pollen grains $/ 1 \mathrm{~g}$

$\mathrm{X}_{6}=7,5 \times 5000=37.5^{*} 10^{3}$ pollen grains $/ 1 \mathrm{~g}$

$\mathrm{X}_{7}=8 \times 5000=4^{*} 10^{4}$ pollen grains $/ 1 \mathrm{~g}$

$\mathrm{X}_{8}=7,5 \times 5000=37.5^{*} 10^{3}$ pollen grains $/ 1 \mathrm{~g}$

$X_{9}=8 \times 5000=4^{*} 10^{4}$ pollen grains $/ 1 \mathrm{~g}$

$\mathrm{X}_{10}=8 \times 5000=4^{*} 10^{4}$ pollen grains $/ 1 \mathrm{~g}$

$X^{-}=387500$

s. e. $=4166.7$

\section{RESULTS AND DISCUSSION}

The results from counting pollen grains in bee honey samples collected from experimental apiaries from Qalyubia Governorate and local market in Egypt, produced in 2013, 2014 and 2015 are presented in Tables 1 to 6.

The number of pollen grains of citrus honey samples collected during 2013 from different apiaries in Qalyubia Governorate and local market in Egypt were summarized in Table (1). The number of pollen grains in each gram of citrus honey collected from Kanater $(\mathrm{H} 1)$ significantly came the first in order with an average of $365750 \pm 16951.9$ pollen grains / gram honey. Followed by the samples collected from Tookh (H3), Shalakan (H2), Cairo Univ. (H4), Ain Shams Univ. (H5) and Agri. Ministry 
(H6) without any significant difference between them and their averages were $26750 \pm 2814.9$, $26200 \pm 2493.5,25750 \pm 2445.2,17000 \pm 1658.3$ and $14750 \pm 2187.4$ pollen grains / g honey, respectively. Meanwhile, the number of pollen grains of clover honey samples collected during the same year 2013 from different apiaries in Qalyubia Governorate and local market in Egypt were summarized in Table (2). The number of pollen grains in each gram of clover honey collected from Shalakan (H8) significantly came the first in order and its average was $47750 \pm 2056.5$ pollen grains / $\mathrm{g}$ honey. Followed by the sample collected from Kanater $(\mathrm{H} 7)$ which significantly came the $2^{\text {nd }}$ in order and its average was $35750 \pm 3051.6$ pollen grains / g honey. The samples collected from Cairo Univ. (H11), Tookh (H9) and Agri. Ministry (H10) significantly came the $3^{\text {rd }}$ in order, without any significant difference between them and their averages were $21000 \pm 2114.8,15250 \pm 1416.7$ and 14250 \pm 1750 pollen grains /g honey, respectively. While the sample collected from Ain Shams Univ. (H12) significantly came the last in order and its average was $11000 \pm 1715.9$ pollen grains / $g$ honey without any significant difference with the samples $\mathrm{H} 9$ and $\mathrm{H} 10$.

The number of pollen grains of citrus honey samples collected during $\mathbf{2 0 1 4}$ from different apiaries in Qalyubia Governorate and local market in Egypt were summarized in Table (3). The number of pollen grains in each gram of citrus honey collected from Kanater $(\mathrm{H} 27)$ significantly came the first in order and its average was $88750 \pm 2963.9$ pollen grains / $\mathrm{g}$ honey. Followed by the sample collected from Agri. Ministry (H18) which significantly came the $2^{\text {nd }}$ in order and its average was $54000 \pm 1943.6$ pollen grains / $g$ honey. The samples collected from Ain Shams Univ. (H15) and Gharbia Governorate (H22) significantly came the $3^{\text {rd }}$ in order and their averages were $33500 \pm$ 1870.8 and $31000 \pm 1632.9$ pollen grains / $g$ honey, respectively. But the samples collected from Shalakan $(\mathrm{H} 13)$ and Tookh $(\mathrm{H} 14)$ were the last in order with averages of $18750 \pm 1547.8$ and $18750 \pm$ 1070 pollen grains /g honey, respectively without any significant difference between them. Meanwhile, the number of pollen grains of clover honey samples collected during the same year 2014 from different apiaries in Qalyubia Governorate and local market in Egypt were summarized in Table (4). The number of pollen grains in each gram of clover honey collected from Shoubra El Khimah (H32) and Shalakan (H29) significantly came the first in order and their averages were $110250 \pm$
12469.1 and $109250 \pm 5701.5$ pollen grains / g honey, respectively. Followed by the sample collected from Agri. Ministry ( $\mathrm{H} 16)$ which significantly came the $2^{\text {nd }}$ in order and its average was $70500 \pm$ 4561.3 pollen grains / $g$ honey. While the samples collected from Kanater (H17), Gharbia Governorate (H37) and Ain Shams Univ. (H36) significantly came the last in order and their averages were $23750 \pm 1193.2,17500 \pm 2075$ and $12750 \pm$ 870 pollen grains /g honey, respectively.

The number of pollen grains of citrus honey samples collected during 2015 from different apiaries in Qalyubia Governorate and local market in Egypt were summarized in Table (5). The number of pollen grains in each gram of citrus honey collected from Gharbia Governorate, Tanta (H24) significantly came the first in order and its average was $49500 \pm 1658.3$ pollen grains /g honey. Followed by the samples collected from Sharqia Governorate $(\mathrm{H} 26)$ and Shalakan $(\mathrm{H} 21)$ which significantly came the $2^{\text {nd }}$ in order and their averages were $40500 \pm 2438.1$ and $37250 \pm 1204.7$ pollen grains /g honey, respectively. The samples collected from Kanater (H20) and Tookh (H25) significantly were the $3^{\text {rd }}$ in order and their averages were $28750 \pm 2334.8$ and $22500 \pm 1748$ pollen grains /g honey, respectively. But the sample collected from Gharbia Governorate, Mahallah (H19) significantly came the last in order and its average was $20250 \pm 946.5$ pollen grains / g honey without any significant difference with the sample H25. Meanwhile, the number of pollen grains of clover honey samples collected during the same year 2015 from different apiaries in Qalyubia Governorate and local market in Egypt were summarized in Table (6). The number of pollen grains in each gram of clover honey collected from Gharbia Governorate, Mahallah (H28) significantly came the first in order and its average was $73000 \pm 2549.5$ pollen grains / g honey. Followed by the samples collected from Shalakan (H31) and Kanater (H33) which significantly came the $2^{\text {nd }}$ in order and their averages were $43250 \pm 2008.7$ and $43000 \pm 3452$ pollen grains / $\mathrm{g}$ honey. While the samples collected from Sharqia Governorate (H35) and Tookh (H30) significantly came the $3^{\text {rd }}$ in order and their averages were $32750 \pm 3060.7$ and $26250 \pm$ 1356.6 pollen grains / $g$ honey. But the sample collected from Gharbia Governorate, Tanta (H34) was the last in order and its average was $8750 \pm$ 1455.3 pollen grains / $g$ honey. 

governorate and available honey in local market, Egypt

Table 1. Number of pollen grains / gram of Citrus honey samples collected from different locations at Qalyubia Governorate and local market in 2013

\begin{tabular}{|c|c|c|c|c|c|c|}
\hline \multirow[b]{2}{*}{ Rep. } & \multicolumn{3}{|c|}{ Locations at Qalyubia } & \multicolumn{3}{|c|}{ Local market in Cairo } \\
\hline & $\begin{array}{c}\mathrm{H} 1 \\
\text { Kanater }\end{array}$ & $\begin{array}{c}\mathrm{H} 2 \\
\text { Shalakan }\end{array}$ & $\begin{array}{c}\text { H3 } \\
\text { Tookh }\end{array}$ & $\begin{array}{l}\text { H4 } \\
\text { Cairo } \\
\text { Univ. }\end{array}$ & $\begin{array}{c}\text { H5 } \\
\text { Ain Shams } \\
\text { Univ. }\end{array}$ & $\begin{array}{c}\text { H6 } \\
\text { Agri. } \\
\text { Ministry }\end{array}$ \\
\hline 1 & 175004 & 25000 & 17500 & 30000 & 17500 & 5000 \\
\hline 2 & 320000 & 15000 & 42500 & 15000 & 12500 & 15000 \\
\hline 3 & 350000 & 32000 & 27500 & 20000 & 12500 & 7500 \\
\hline 4 & 237500 & 20000 & 17500 & 15000 & 10000 & 10000 \\
\hline 5 & 382500 & 20000 & 12500 & 22500 & 15000 & 7500 \\
\hline 6 & 392500 & 40000 & 30000 & 30000 & 22500 & 17500 \\
\hline 7 & 417500 & 35000 & 25000 & 32500 & 20000 & 22500 \\
\hline 8 & 372500 & 20000 & 32500 & 22500 & 25000 & 20000 \\
\hline 9 & 387500 & 30000 & 30000 & 35000 & 12500 & 17500 \\
\hline 10 & 380000 & 25000 & 32500 & 35000 & 22500 & 25000 \\
\hline $\begin{array}{c}\text { Mean(x) } \\
\pm \\
\text { s. e. }\end{array}$ & $\begin{array}{c}365750^{a} \\
\pm \\
16951.9\end{array}$ & $\begin{array}{c}26200^{b} \\
\pm \\
2493.5\end{array}$ & $\begin{array}{l}26750^{\mathrm{b}} \\
\pm \\
2814.9\end{array}$ & $\begin{array}{c}25750^{b} \\
\pm \\
2445.2\end{array}$ & $\begin{array}{c}17000^{b} \\
\pm \\
1658.3\end{array}$ & $\begin{array}{c}14750^{b} \\
\pm \\
2187.4\end{array}$ \\
\hline
\end{tabular}

L.S.D. 42617 pollen grains / $g$ honey

Table 2. Number of pollen grains / gram of Clover honey samples collected from different locations at Qalyubia Governorate and local market in 2013

\begin{tabular}{|c|c|c|c|c|c|c|}
\hline \multirow[b]{2}{*}{ Rep. } & \multicolumn{3}{|c|}{ Locations at Qalyubia } & \multicolumn{3}{|c|}{ Local market in Cairo } \\
\hline & $\begin{array}{c}\mathrm{H7} \\
\text { Kanater }\end{array}$ & $\begin{array}{c}\text { H8 } \\
\text { Shalakan }\end{array}$ & $\begin{array}{c}\text { H9 } \\
\text { Tookh }\end{array}$ & $\begin{array}{l}\text { H11 } \\
\text { Cairo } \\
\text { Univ. }\end{array}$ & $\begin{array}{c}\text { H12 } \\
\text { Ain } \\
\text { Shams } \\
\text { Univ. }\end{array}$ & $\begin{array}{c}\text { H10 } \\
\text { Agri. } \\
\text { Ministry }\end{array}$ \\
\hline 1 & 35000 & 52500 & 17500 & 20000 & 12500 & 15000 \\
\hline 2 & 45000 & 55000 & 12500 & 20000 & 5000 & 12500 \\
\hline 3 & 37500 & 50000 & 7500 & 20000 & 7500 & 10000 \\
\hline 4 & 35000 & 57500 & 10000 & 30000 & 2500 & 10000 \\
\hline 5 & 20000 & 45000 & 15000 & 15000 & 10000 & 12500 \\
\hline 6 & 20000 & 42500 & 15000 & 25000 & 10000 & 10000 \\
\hline 7 & 35000 & 50000 & 22500 & 17500 & 10000 & 10000 \\
\hline 8 & 42500 & 37500 & 20000 & 10000 & 15000 & 27500 \\
\hline 9 & 50000 & 40000 & 15000 & 20000 & 17500 & 17500 \\
\hline 10 & 37500 & 47500 & 17500 & 32500 & 20000 & 17500 \\
\hline $\begin{array}{c}\text { Mean(x) } \\
\pm \\
\text { s. e. }\end{array}$ & $\begin{array}{c}35750^{b} \\
\pm \\
3051.6\end{array}$ & $\begin{array}{c}47750^{a} \\
\pm \\
2056.5\end{array}$ & $\begin{array}{c}15250 \text { cd } \\
\pm \\
1416.7\end{array}$ & $\begin{array}{c}21000^{c} \\
\pm \\
2114.8\end{array}$ & $\begin{array}{c}11000^{d} \\
\pm \\
1715.9\end{array}$ & $\begin{array}{c}14250^{\mathrm{cd}} \\
\pm \\
1750\end{array}$ \\
\hline
\end{tabular}

L.S.D. 8702.4 pollen grains / $\mathrm{g}$ honey 
Table 3. Number of pollen grains / gram of Citrus honey samples collected from different locations at Qalyubia Governorate and local market in 2014

\begin{tabular}{|c|c|c|c|c|c|c|}
\hline \multirow[t]{2}{*}{ Honey samp. } & \multicolumn{3}{|c|}{ Locations at Qalyubia } & \multicolumn{3}{|c|}{ Local market in Gharbia and Cairo } \\
\hline & $\begin{array}{c}\mathrm{H} 27 \\
\text { Kanater }\end{array}$ & $\begin{array}{c}\text { H13 } \\
\text { Shalakan }\end{array}$ & $\begin{array}{c}\text { H14 } \\
\text { Tookh }\end{array}$ & $\begin{array}{c}\text { H22 } \\
\text { Gharbia }\end{array}$ & $\begin{array}{c}\text { H15 } \\
\text { Ain } \\
\text { Shams } \\
\text { Univ. }\end{array}$ & $\begin{array}{c}\text { H18 } \\
\text { Agri. } \\
\text { Ministry }\end{array}$ \\
\hline 1 & 75000 & 10000 & 15000 & 35000 & 45000 & 47500 \\
\hline 2 & 77500 & 17500 & 15000 & 25000 & 35000 & 47500 \\
\hline 3 & 87500 & 22500 & 17500 & 25000 & 37500 & 52500 \\
\hline 4 & 85000 & 20000 & 17500 & 35000 & 27500 & 55000 \\
\hline 5 & 100000 & 27500 & 17500 & 27500 & 32500 & 65000 \\
\hline 6 & 95000 & 22500 & 22500 & 25000 & 27500 & 60000 \\
\hline 7 & 92500 & 15000 & 17500 & 32500 & 27500 & 60000 \\
\hline 8 & 102500 & 15000 & 17500 & 32500 & 40000 & 50000 \\
\hline 9 & 92500 & 17500 & 22500 & 32500 & 32500 & 47500 \\
\hline 10 & 80000 & 20000 & 25000 & 40000 & 30000 & 55000 \\
\hline $\begin{array}{c}\text { Mean(x) } \\
\pm \\
\text { s. e. }\end{array}$ & $\begin{array}{c}88750^{a} \\
\pm \\
2963.9\end{array}$ & $\begin{array}{c}18750^{d} \\
\pm \\
1547.8\end{array}$ & $\begin{array}{c}18750^{d} \\
\pm \\
1070.4\end{array}$ & $\begin{array}{c}31000^{c} \\
\pm \\
1632.9\end{array}$ & $\begin{array}{c}c_{33500} \\
\pm \\
1870.8\end{array}$ & $\begin{array}{c}54000^{b} \\
\pm \\
1943.6\end{array}$ \\
\hline
\end{tabular}

L.S.D. 7374 pollen grains / $g$ honey

Table 4. Number of pollen grains / gram of Clover honey samples collected from different locations at Qalyubia Governorate and local market in 2014

\begin{tabular}{|c|c|c|c|c|c|c|}
\hline \multirow[b]{2}{*}{ Rep. } & \multicolumn{3}{|c|}{ Locations at Qalyubia } & \multicolumn{3}{|c|}{ Local market in Gharbia and Cairo } \\
\hline & $\begin{array}{c}\mathrm{H} 17 \\
\text { Kanater }\end{array}$ & $\begin{array}{c}\text { H29 } \\
\text { Shalakan }\end{array}$ & $\begin{array}{c}\text { H32 } \\
\text { Shoubra } \\
\text { El-khimah }\end{array}$ & $\begin{array}{c}\text { H37 } \\
\text { Gharbia }\end{array}$ & $\begin{array}{c}\text { H36 } \\
\text { Ain } \\
\text { Shams } \\
\text { Univ. }\end{array}$ & $\begin{array}{c}\text { H16 } \\
\text { Agri. } \\
\text { Ministry }\end{array}$ \\
\hline 1 & 20000 & 90000 & 77500 & 22500 & 10000 & 50000 \\
\hline 2 & 25000 & 102500 & 112500 & 5000 & 17500 & 65000 \\
\hline 3 & 25000 & 120000 & 90000 & 20000 & 50001 & 85000 \\
\hline 4 & 27500 & 85000 & 70000 & 15000 & 10000 & 57500 \\
\hline 5 & 17500 & 97500 & 137500 & 17500 & 10000 & 62500 \\
\hline 6 & 20000 & 127500 & 95000 & 10000 & 12500 & 55000 \\
\hline 7 & 30000 & 140000 & 185000 & 15000 & 10000 & 82500 \\
\hline 8 & 25000 & 112500 & 165000 & 20000 & 12500 & 72500 \\
\hline 9 & 22500 & 95000 & 80000 & 22500 & 15000 & 90000 \\
\hline 10 & 25000 & 122500 & 90000 & 27500 & 15000 & 85000 \\
\hline $\begin{array}{c}\text { Mean(x) } \\
\pm \\
\text { s. e. }\end{array}$ & $\begin{array}{c}23750^{c} \\
\pm \\
1193.2\end{array}$ & $\begin{array}{c}109250^{\mathrm{a}} \\
\pm \\
5701.5\end{array}$ & $\begin{array}{c}110250^{\mathrm{a}} \\
\pm \\
12469.1\end{array}$ & $\begin{array}{c}17500^{c} \\
\pm \\
2075\end{array}$ & $\begin{array}{c}12750^{c} \\
\pm \\
870\end{array}$ & $\begin{array}{c}70500^{b} \\
\pm \\
4561.3\end{array}$ \\
\hline
\end{tabular}

L.S.D. 25028 pollen grains / $\mathrm{g}$ honey 

governorate and available honey in local market, Egypt

Table 5. Number of pollen grains / gram of Citrus honey samples collected from different locations at Qalyubia Governorate and local market in $\mathbf{2 0 1 5}$

\begin{tabular}{|c|c|c|c|c|c|c|}
\hline \multirow[b]{2}{*}{ Rep. } & \multicolumn{3}{|c|}{ Locations at Qalyubia } & \multicolumn{3}{|c|}{ Local market Gharbia and Sharqeia } \\
\hline & $\begin{array}{c}\mathrm{H} 20 \\
\text { Kanater }\end{array}$ & $\begin{array}{c}\text { H21 } \\
\text { Shalakan }\end{array}$ & $\begin{array}{c}\text { H25 } \\
\text { Tookh }\end{array}$ & $\begin{array}{c}\text { H19 } \\
\text { Gharbia } \\
\text { (Mahallah) }\end{array}$ & $\begin{array}{c}\text { H24 } \\
\text { Gharbia } \\
\text { (Tanta) }\end{array}$ & $\begin{array}{c}\mathrm{H} 26 \\
\text { Sharqeia }\end{array}$ \\
\hline 1 & 20000 & 32500 & 27500 & 20000 & 52500 & 27500 \\
\hline 2 & 27500 & 35000 & 22500 & 20000 & 42500 & 37500 \\
\hline 3 & 37500 & 32500 & 15000 & 17500 & 50000 & 42500 \\
\hline 4 & 27500 & 35000 & 15000 & 15000 & 60000 & 30000 \\
\hline 5 & 37500 & 45000 & 20000 & 22500 & 45000 & 47500 \\
\hline 6 & 27500 & 37500 & 20000 & 17500 & 55000 & 35000 \\
\hline 7 & 37500 & 40000 & 32500 & 22500 & 47500 & 42500 \\
\hline 8 & 32500 & 40000 & 27500 & 20000 & 45000 & 45000 \\
\hline 9 & 17500 & 37500 & 22500 & 25000 & 50000 & 50000 \\
\hline 10 & 22500 & 37500 & 22500 & 22500 & 47500 & 47500 \\
\hline $\begin{array}{c}\text { Mean(x) } \\
\pm \\
\text { s. e. }\end{array}$ & $\begin{array}{c}28750^{c} \\
\pm \\
2334.8\end{array}$ & $\begin{array}{c}37250^{b} \\
\pm \\
1204.7\end{array}$ & $\begin{array}{c}22500^{c d} \\
\pm \\
1748\end{array}$ & $\begin{array}{c}20250^{d} \\
\pm \\
946.5\end{array}$ & $\begin{array}{c}49500^{a} \\
\pm \\
1658.3\end{array}$ & $\begin{array}{c}40500^{b} \\
\pm \\
2438.1\end{array}$ \\
\hline
\end{tabular}

L.S.D. 7541.9 pollen grains / $\mathrm{g}$ honey

Table 6. Number of pollen grains / gram of Clover honey samples collected from different locations at Qalyubia Governorate and local market in 2015

\begin{tabular}{|c|c|c|c|c|c|c|}
\hline \multirow{2}{*}{ Honey samp. } & \multicolumn{3}{|c|}{ Locations at Qalyubia } & \multicolumn{3}{c|}{ Local market in Gharbia and } \\
Sharqeia
\end{tabular}

L.S.D. 10203 pollen grains / g honey 
As shown in Table (7) the honey samples (collected during the 3 years 2103, 2014 and 2015) were classified according to the categories of Leaveaux, et al 1978, as follows:

- $2.8 \%$ of the samples were poor in their content of pollen grains (2000-10000 pollen grains/ $\mathrm{g}$ honey).

- $77.8 \%$ of the samples were rich in their content of pollen grains(10000-50000pollen grains/g honey).

- $11.1 \%$ of the samples were more rich in their content of pollen grains (50000-100000 pollen grains/g honey).

$8.3 \%$ of the samples were very rich in their content of pollen grains (>100000 pollen grains/ $g$ honey).

Table 7. Percentages of the 36 honey samples (collected during the 3 years 2013, 2014 and 2015) in each category of the Leaveaux, et al 1978 categories, according to their content of pollen grains

\begin{tabular}{|c|c|c|}
\hline $\begin{array}{l}\text { Categories of } \\
\text { Leaveaux, et al } \\
1978 \text { (pollen } \\
\text { grains/g honey) }\end{array}$ & $\begin{array}{c}\text { No. of } \\
\text { honey } \\
\text { samples }\end{array}$ & $\begin{array}{c}\text { Percentages of } \\
\text { honey } \\
\text { samples in } \\
\text { each category }\end{array}$ \\
\hline 1. $<2000$ & 0 & 0 \\
\hline 2. $2000-10000$ & 1 & 2.8 \\
\hline 3. $10000-50000$ & 28 & 77.8 \\
\hline 4. $50000-100000$ & 4 & 11.1 \\
\hline 5. $>100000$ & 3 & 8.3 \\
\hline Total & 36 & 100 \\
\hline
\end{tabular}

\section{REFERENCES}

Delaplane, K.S., Dag, A., Danka, R.G., Freitas, B.M., Garibaldi, L.A., Goodwin, R.M. and Hormaza, J.I. 2013. Standard methods for pollination research with Apis mellifera. Cited from Dikov, D. (2015). Quantitative melissopalynological analysis of bee honey using a Burker chamber. International food research journal, 22 (4), 1538-1543.

El-Sherbiny, G.A., Rizk, S.S., El-Ashwah, F.A. and Heikel, H.A. 1980. Chemical composition of citrus honey produced in A.R.E. Agri. Res. Rev., 58, 289- 297.

Faraj, R.M.A. 2007. Studies on Egyption honeys. M. Sc. Thesis, Plant Protection Dept., Fac. Agric., Cairo Univ., Egypt 183 p.

Gomaa, W.M.K. 2002. Studies on honey quality with special reference to the Egyptian honey standard. M. Sc.Thesis, Plant Protection Dept., Fac. Agric., Alexandria Univ.,, Egypt 156 p.

Hassan, Mona, I.M. 1985. Studies on food: Effect of storage on some physical and chemical characteristics of bee honey. M. Sc. Thesis, Plant Protection Dept., Fac. Agric., Alexandria Univ., Egypt 286 p.

Heldrup, J., Kalm, O. and Prellner, K. 1992. Blood $\mathrm{T}$ and $\mathrm{B}$ lymphocyte subpopulations in healthy infants and children. Acta Paediatrica; 81(2), 125-132.

Hornitzy, M. 2009. Nosema diagnosis. Downloaded from http://www.dpi.nsw.gov.au/data/assets/pdf.

Human, H., Brodschneider, R., Dietemann, V., Dively, F., Ellis, G., Forsgren, J., Fries, E., Hatjina, F., Jaffè, R., Jensen, A.B., Köhler, A., Magyar, J., Özkýrým, C.W.W., Pirk, C.W.W., Rose, R., Strauss, U., Tanner, G., Tarpy, D. R., van der Steen, J.J.M., Vaudo, A., Vejsnaes, F., Wilde, J., Williams, G.R. and Zheng, H.Q. 2013. Miscellaneous standard methods for Apis mellifera research. Cited from Dikov, D. (2015). Quantitative melissopalynological analysis of bee honey using a Burker chamber. International Food Research Journal, 22 (4), 1538-1543.

Ismail, A.M., Owayss, A.A., Mohanny, K.M. and Salem, R.A. 2013. Evaluation of pollen collected by honey bee, Apis mellifera L. colonies at Fayoum Governorate, Egypt. Part : Botanical origin. Journal of the Saudi Society of Agricultural Sciences, 12, 129-135.

Louveaux, J., Maurizio, A. and Vorwohl, G. 1978. Methods of Melissopalynology. Bee World; 59, 139-157.

Neubauer's improved cell counting chamber 2003. Downloaded from http://insilico.e hu.es/counting chamber/neubauer improved.p df.

Nour, M.E. 1988. Some factors affecting quality of Egyptian honey. Ph. D. Thesis, Plant Protection Dept., Fac. Agric., Cairo Univ., Egypt 252p.

Oddo, L.P. and Piro, R. 2004. Main European unifloral honeys: descriptive sheets. Apidologie; 35(1), S38-S81.

Rateb, S.H. 2005. Studies on pollen spectrum, chemical and physical characters of honeys. Ph. D. Thesis, Plant Protection Dept., Fac. Agric., Assiut Univ., Egypt 332 p.

von der Ohe, W., Oddo, L.P., Piana, M.L., Morlot, M. and Martin, P. 2004. Harmonized methods of melissopalynology. Apidologie; 35, S18-S25. 